\title{
Training of motor rhythm in students, practicing football
}

\author{
Polevoy G. G. \\ Vyatka State University, Kirov, Russia
}

\begin{abstract}
Purpose:

to test the methodic of students' motor rhythm training at physical culture lessons based on application of football means.

Material: $\quad$ in the research full time $1^{\text {st }}$ year students of main health group $(n=40)$ participated. After short warming up $(10-15$ minutes) they fulfilled exercises for rhythm feeling during 15 minutes at every lesson. Assessment of rhythm feeling was carried out with the help of test "Ball pulling by foot". Shuttle run $3 \times 10 \mathrm{~m}$ was used for assessment of general coordination level. Besides, complex test for football player's technical fitness (juggling, dribbling, dribbling around stands and kicking goal) was used.

Results: $\quad$ we found that it is necessary to selectively train football player's ability for motor rhythm. It also concerns training of students' coordination. We presented new opportunities of application of methodic of students' motor rhythm's development. These opportunities were realized at physical culture lessons, based on football means.

Conclusions: when mastering and practicing new and complex exercises for coordination we used the method of standardrepeated exercise. The method of variable exercise was used, when it was necessary to change the mean of movements' fulfillment. Game and competition methods were used only, when the trained motor action became automatic.

Keywords: $\quad$ students, coordination abilities, rhythm, physical education, technical fitness.
\end{abstract}

\section{Introduction}

The questions, connected with coordination training and its structure's determination are the objects of many scientific researches $[1,3,4]$.

General coordination abilities are abilities to purposefully and rationally solve complex motor tasks [6, $14,15]$. Such abilities are the foundation for development of specific coordination. For achievement high results in motor activity it is necessary to have high level of specific coordination [16]. For training motor rhythm it is necessary to consider and use the following:

- Didactic laws of motor actions' formation [25, 37];

- Individual and group models of motor actions' construction $[23,26]$;

- Modern technologies of education and training [22, 31];

- Adequate forms of pedagogic control [27, 30];

- Models of successfulness prediction [24, 32];

- Correlation of anthropometric and functional indicators [21, 33];

- Criteria of motor coordination structure [19, 29, 33];

- Psychological indicators of reaction to physical load $[20,28]$ considering health level $[35,36]$.

Specific for football coordination abilities are those, which ensure optimal control of specific motor tasks' fulfillment. Such tasks simulate separate sides of competition activity in football [16].

Among numerous specific coordination abilities we can mark out 7 the most important (basic) abilities, which influence on football player's technical skillfulness [12, 18]:

1) motor rhythm feeling;

2) kinesthetic differentiation of motor parameters (feeling of ball);

3) orientation in space;

4) coordination (combining) of movements;

5) quick reaction;

6) adaptation and reconstruction of movements;

7) keeping balance in dynamic and static conditions.

(c) Polevoy G. G., 2017

doi:10.15561/20755279.2017.0407
In our opinion, from the enlisted above abilities ability to feel motor rhythm is of special importance for football player's technical training. It implies correct and accurate reproduction of preset rhythm of motor action or its adequate varying, depending on changing conditions [12].

Thus, ability for motor rhythm is one of components of football player's technical fitness. Importance of this task's solution is underlined in most of works, devoted to coordination problems.

Hypothesis: it is assumed that with the help of motor rhythm training means and methods it is possible to improve coordination indicators and technical fitness of students, who practice football at physical culture lessons.

The purpose of the research is to substantiate and experimentally test the methodic of students' motor rhythm training at physical culture lessons, based on application of football means.

\section{Material and methods}

Participants: in the research full time $1^{\text {st }}$ year students of main health group $(n=40),(17-18$ years age) participated.

Organization of the research: the researches were conducted on the base of Vyatka State University, (Kirov, Russia).

Experimental group (EG) was completed by method of random sampling [2]. CG was trained by traditional physical education program [17]. EG trainings included exercises for rhythm. In both groups training were conducted twice a week (two academic hours each). In total we conducted 64 academic training hours in every group.

Specificities of experimental methodic of EG students:

1) After short warming up (10-15 minutes) they fulfilled exercises for rhythm feeling during 15 minutes at every lesson.

2) Load was increased gradually. Rising of intensity was at the account of increase of exercises' quantity and shortening of rest intervals between exercises and (or) series of exercises. 
3) The most effective means for football players' rhythm feeling are: dribbling with changing of temp and direction; Jumps between irregularly laid sticks; slalom dribbling; running hurdles; running with preset time of segments' run 10, 20,30 meters; kicking ball after rebound from wall (or after partner's pass) $[7,9,15]$.

4) When training and fulfilling new and complex coordination exercises we used the method of standard repeated exercise. The method of variable exercise was used, when there was need in changing of mean of these exercises' fulfillment. Game and competition methods were used, when the trained action became automatic.

We also used the method of pedagogic testing and determined the following indicators: ability for rhythm, general coordination abilities; technical fitness (all tests were fulfilled on site for mini-football:

1) Assessment of rhythm feeling was carried out with the help of test "Ball pulling by foot".

Initial position is stance with both feet on floor. By signal it is necessary to pull ball backward by sole as quick as possible. After every contact with ball sole shall touch the floor (10 times). After tenth contact of sole with ball student shall touch the floor with foot. After it, stopwatch is switched off. Results: the best from two attempts is registered with accuracy up to $0.01 \mathrm{sec}$. [12].

2) Shuttle run $3 \times 10 \mathrm{~m}$ was used for assessment of general coordination level.

Two parallel lines are drawn on the floor at 10 meters' distance on start and finish. Student stands behind start line. By command "Go" he runs to finish line, touches it with fingers of one hand and return to start line. Then, he repeats this exercise 3 times. Results: the best from two attempts is registered with accuracy up to $0.01 \mathrm{sec}$. [11].

3) Complex test for football player's technical fitness implies juggling, dribbling, dribbling around stands and kicking goal.

The exercise is started with juggling (three ball touches with foot). Than - "snake" dribbling: it means dribbling around 4 stands (distance between stands -2.5 meters) and kick goal (not entering penalty box). The time is registered from the moment of start to ball's crossing the line of goal. If goal is not hit - exercises is failed. Result: the best from two attempts is registered with accuracy up to $0.01 \mathrm{sec} .17]$.

Statistical analysis: For determination of pedagogic experiment's results' confidence the data were processed with the help of mathematical statistic methods. We used parametrical criterion (Student's t-test). Statistical processing was carried out with Microsoft Excel 2007 standard statistical programs. Results at $\mathrm{P}>0.01$ were considered to be confident.

\section{Results:}

At the beginning of experiment testing did not show confident differences between all tested indicators of EG and CG $(\mathrm{P}>0.05)$. After pedagogic experiment we received the following results, presented in table 1 .

Analysis of table 1 showed that there happened some changes during pedagogic experiment. In test "Ball pulling by foot (sec.)" normal is result, not exceeding 4.5 sec. [4].

Before experiment both EG and CG indicators were below norm. After experiment EG indicators improved from 5.0 \pm 0.1 to $4.3 \pm 0.2(\mathrm{P}<0.01)$; in $\mathrm{CG}$ indicators also improved but insignificantly - by $0.1 \pm 0.1(\mathrm{P}>0.01)$ : that is below norm of ability to motor rhythm.

For $1^{\text {st }}$ year students in test "Shuttle run $3 \times 10$ " norm is period from $7.3 \mathrm{sec}$. to $8.2 \mathrm{sec}$. $7.3 \mathrm{sec}$. means "excellent", 8.0 - "good" and 8.2 - "satisfactory" [17].

Before experiment results of both groups were "satisfactory". After experiment, CG indicators improved up to "good" $-7.9 \pm 0.2(\mathrm{P}>0.01)$.

Indicators of $\mathrm{EG}$ after experiment showed significant positive increment by $1.0 \pm 0.2(\mathrm{P}<0.01)$ that corresponded to "excellent".

"Test passed" was put for complex test for technical fitness, if result did not exceed $8 \mathrm{sec}$. [17].

Before experiment both EG and CG students did not receive "test passed".

After experiment EG indicators noticeably improved:

Table 1. EG and CG students' indicators from the beginning and up to the end of experiment

\begin{tabular}{|c|c|c|c|c|}
\hline Indicators & Group & Before & After & $\mathbf{P}$ \\
\hline \multirow{3}{*}{$\begin{array}{l}\text { Ball pulling by foot } \\
\text { (sec.) }\end{array}$} & EG & $5,0 \pm 0,1$ & $4,3 \pm 0,2$ & $P<0,01$ \\
\hline & CG & $4,9 \pm 0,1$ & $4,8 \pm 0,1$ & $P>0,01$ \\
\hline & $P$ & $P>0,01$ & $P<0,01$ & - \\
\hline \multirow{3}{*}{$\begin{array}{l}\text { Shuttle run } 3 \times 10 \\
\text { (sec.) }\end{array}$} & EG & $8,2 \pm 0,2$ & $7,2 \pm 0,2$ & $P<0,01$ \\
\hline & CG & $8,1 \pm 0,2$ & $7,9 \pm 0,2$ & $P>0,01$ \\
\hline & $P$ & $P>0,01$ & $P<0,01$ & - \\
\hline \multirow{3}{*}{$\begin{array}{l}\text { Test for technical } \\
\text { fitness (sec.) }\end{array}$} & EG & $8,3 \pm 0,2$ & $7,2 \pm 0,2$ & $P<0,01$ \\
\hline & CG & $8,1 \pm 0,2$ & $7,9 \pm 0,1$ & $P>0,01$ \\
\hline & $\mathrm{P}$ & $P>0,01$ & $P<0,01$ & - \\
\hline
\end{tabular}


up to $7.2 \pm 0.2(\mathrm{P}<0.01)$. In $\mathrm{CG}$ indicators also improved but not so significantly: only to $7.9 \pm 0.1$ ( $\mathrm{P}>0.01)$

It should be noted that before experiment there were no confident between EG and CG $(\mathrm{P}>0.01)$. After experiment EG students were ahead of CG by all indicators $(\mathrm{P}<0.01)$.

\section{Discussion}

Technical fitness of football player is influenced by his coordination abilities $[5,7,12]$. The authors underline key importance of specific coordination abilities of different sportsmanship and age athletes.

Coordination abilities are rather diverse and classified in different ways [4, 10, 12]. Most of authors [4, 8, 13] recommended training equally all known abilities, including ability for motor rhythm.

Analysis of researches points at demand in selective training of football player's motor rhythm. It relates also to development students' coordination abilities.

The novelty of the research is that we present new opportunities for methodic of students' motor rhythm training. These opportunities were realized at physical culture lessons, based on football means. We received positive results of this methodic application.

However, there are some prospects in studies of coordination abilities. For example, they are: influence on football players' technical fitness, ability for quick reacting and orientation in space. Besides, it is possible to conduct complex functional and anthropometric assessment of students. Such approach will permit to monitor students' health condition; correct training process; achieve high health related or sport results.

\section{Conclusions:}

The used means and methods of motor rhythm abilities' development improved students', practicing football, coordination abilities and technical fitness.

The received data are of practical interest for coaches and teachers of higher educational establishments.

\section{Conflict of interests}

The author declares that there is no conflict of interests.

\section{References}

1. Aver'ianov IV. Methodic of perfection of 10-11 years age football players' kinesthetic coordination abilities. Cand. Diss. Omsk; 2008. (in Russian)

2. Afanas'ev VV, Nepriaev IN. Mathematical statistic in team kinds of sports. Yaroslavl: YAGPU; 2007. (in Russian)

3. Bojchenko SD, Karseko EN, Leonov VV, Smotrickij AL. On some aspects of coordination and coordination abilities conception in physical education and sport training. Teoriia $i$ praktika fizicheskoj kul 'tury. 2003;8:15-18. (in Russian)

4. Vitkovski Z, Liakh VI. Coordination abilities in football: diagnostic, prediction of development, training. Fizicheskaia kul 'tura: vospitanie, obrazovanie, trenirovka. 2006;4:28-31. (in Russian)

5. Golomazov SV, Chirva BG. Theory and methodic of football. Technique of game. Moscow: Sports of Academic Press; 2002. (in Russian)

6. Gorskaia IIu. Assessment of coordination fitness in sports. Teoriia i praktika fizicheskoj kul'tury, 2010;7:34-37. (in Russian)

7. Grigor'ian MR. Technical fitness of junior football players, considering differentiation of specialized loads of increased coordination difficulty. Cand. Diss. Krasnodar; 2009. (in Russian)

8. Gusev IuA. Methodic ofjunior handball players' coordination abilities, based on simulation of competition functioning conditions. Cand. Diss. Volgograd; 2003. (in Russian)

9. Kol'vakh IuV. Regulation of specialized loads of different coordination difficulty of elite football players in preparatory period. Cand. Diss. Krasnodar; 2006. (in Russian)

10.Kondakov AM. Technical-tactic training of 11-12 yrs age sambo wrestlers by means of special coordination exercises, considering age categories. Cand. Diss. Omsk; 2010. (in Russian)

11.Landa BKh. Methodic of complex assessment of physical condition and physical fitness. Moscow: Soviet sport; 2008. (in Russian)

12.Liakh VI, Vitkovski Z, Zhmuda V. Specofoc coordination abilities as criterion of prediction of football players' sport achievements. Teoriia i praktika fizicheskoj kul'tury,
2002;4:21-25. (in Russian)

13.Liakh VI, Vitkovski Z. Coordination training in football. Moscow: Soviet sport; 2010. (in Russian)

14.Matveev LP. General theory of sorts and its applied aspects. Moscow: Soviet sport; 2010. (in Russian)

15.Monakov GV. Training of football players. Pskov: Physical Culture and Sport; 2009. (in Russian).

16.Polevoj GG. Training of 11-12 yrs age football players specific coordination, considering specificities of their nervous systems. Cand. Diss. Kirov; 2015. (in Russian)

17.Reshetnikov NV, Kislicyn IuL. Physical culture. Moscow: Academy; 2005. (in Russian)

18.Shamonin AV. Rising of technical fitness in training balance of 7-11 yrs age junior football players. Cand. Diss. Moscow; 2010. (in Russian)

19.Bardaglio G, Marasso D, Magno F, Rabaglietti E, Ciairano S. Team-teaching in physical education for promoting coordinative motor skills in children: the more you invest the more you get. Physical Education and Sport Pedagogy. 2015;20(3):268-82.

20.Barnett LM, Stodden D, Cohen KE, Smith JJ, Lubans DR, Lenoir M, et al. Fundamental Movement Skills: An Important Focus. Journal of Teaching in Physical Education. 2016;35(3):219-25.

21.Correia V, Passos P, Araujo D, Davids K, Diniz A, Kelso JAS. Coupling tendencies during exploratory behaviours of competing players in rugby union dyads. European Journal of Sport Science. 2016;16(1):11-9.

22.Druz VA, Iermakov SS, Artemyeva GP, Puhach YI, Muszkieta R. Individualization factors of students' physical education at modern stage of its realization. Physical education of students, 2017; 21(1): 10-16. doi:10.15561/20755279.2017.0102

23.Druz VA, Iermakov SS, Nosko MO, Shesterova LYe, Novitskaya NA. The problems of students' physical training individualization. Pedagogics, psychology, medicalbiological problems of physical training and sports, 2017; 21(2): 4-12. doi:10.15561/18189172.2017.0201

24.Gaskov AV, Kuzmin VA, Kudryavtsev DM, Iermakov SS. Successfulness of general and special physical qualities' development on different stage of students-boxers' 
training. Physical Education of Students. 2016;20(1):4-11. $10.15561 / 20755279.2016 .0101$

25.Iermakov SS, Arziutov GN, Jagiello W. Quick training of students to judo techniques. Archives of Budo. 2016;12:1524.

26.Iermakov SS, Podrigalo LV, Jagiello W. Hand-grip strength as an indicator for predicting the success in martial arts athletes. Archives of Budo. 2016;12:179-86.

27.Khudolii OM, Ivashchenko OV, Iermakov SS, Rumba OG. Computer simulation of Junior gymnasts' training process. Science of Gymnastics Journal, 2016;8(3):215-228.

28.Kozina ZL, Iermakov SS, Kadutskaya LA, Sobyanin FI, Krzeminski M, Sobko IN, Ryepko OA. Comparative characteristic of correlation between pulse subjective indicators of girl students' and school girls' reaction to physical load. Physical Education of Students. 2016;20(4):2434. doi:10.15561/20755279.2016.0403

29.Lhuisset L, Margnes E. The influence of live- vs. videomodel presentation on the early acquisition of a new complex coordination. Physical Education and Sport Pedagogy. 2015;20(5):490-502.

30.Lleixa T, Gonzalez-Arevalo C, Braz-Vieira M. Integrating key competences in school physical education programmes. European Physical Education Review. 2016;22(4):506-25.

31.Osipov AY, Kudryavtsev MD, Kramida IE, Iermakov SS, Kuzmin VA, Sidorov LK. Modern methodic of power cardio training in students' physical education. Physical Education of Students. 2016;20(6):34-9. doi:10.15561/20755279.2016.0604
32.Podrigalo LV, Galashko M N, Iermakov SS, Rovnaya OA, Bulashev AY. Prognostication of successfulness in armwrestling on the base of morphological functional indicators' analysis. Physical education of students, 2017; 21(1): 46-51. doi:10.15561/20755279.2017.0108

33.Podrigalo LV, Iermakov SS, Jagiełł W. Special indices of body composition as a criterion of somatic development of martial arts practitioners. Arch Budo Sci Martial Art Extreme Sport 2017; 13: 5-12

34.Pryimakov AA, Eider E, Nosko MO, Iermakov SS. Reliability of functioning and reserves of system, controlling movements with different coordination structure of special health group girl students in physical education process. Physical education of students, 2017; 21(2): 84-89. doi:10.15561/20755279.2017.0206

35.Radziminska A，Weber-Rajek M, Lulinska-Kuklik E, Kazmierczak U, Moska W. Academic youth's health behavior. Physical education of students, 2016; 20(6): 55-62. doi:10.15561/20755279.2016.0607

36.Radzimińska A, Weber-Rajek M, Lulińska-Kuklik E, Piecka P, Moska W. The impact of classical massage on spine mobility. Pedagogics, psychology, medical-biological problems of physical training and sports, 2017; 21(2): 82-86. doi:10.15561/18189172.2017.0206

37.Vors O, Gal-Petitfaux N, Potdevin F. A successful form of trade-off in compensatory policy classrooms: Processes of ostentation and masking. A case study in French physical education. European Physical Education Review. 2015;21(3):340-61

\section{Information about the author:}

Polevoy G. G.; http://orcid.org/0000-0002-3300-3908; gera_lider1@mail.ru; Vyatka State University; Moscow str., 36, Kirov, 610000, Russia.

Cite this article as: Polevoy GG. Training of motor rhythm in students, practicing football. Physical education of students, 2017;21(4):189-192. doi:10.15561/20755279.2017.0407

The electronic version of this article is the complete one and can be found online at: http://www.sportedu.org.ua/index.php/PES/issue/archive

This is an Open Access article distributed under the terms of the Creative Commons Attribution License, which permits unrestricted use, distribution, and reproduction in any medium, provided the original work is properly cited (http://creativecommons.org/licenses/by/4.0/deed.en).

Received: 16.05 .2017

Accepted: 27.05.2017; Published: 10.08.2017 